\section{Géneros}

Multidisciplinary Journal of Gender: Studies
Hipatia Press

www.hipatiapress.com

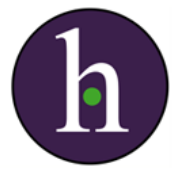

Instructions for authors, subscriptions and further details:

http://generos.hipatiapress.com

\title{
Becoming and Being a Women: Meanings and Values of Labial Elongation for Zambians in Cape Town
}

Guillermo Martínez Pérez ${ }^{1}$

Concepción Tomás Aznar ${ }^{1}$
Mwenya Mubanga ${ }^{2}$

Brigitte Bagnol $^{3}$

1) Universidad de Zaragoza, Spain

2) Uppsala University, Sweden

3) University of the Witwatersrand, South Africa

Date of publication: June $25^{\text {th }}, 2016$

Edition period: June - October 2016

To cite this article: Martínez - Pérez, G., Mwenya, M., Tomás-Aznar, C., \& Bagnol, B. (2016). Becoming and Being a Women: Meaning and Values of Labial Elongation for Zambians in Cape Town. Géneros.

Multidisciplinary Journal of Gender Studies, 5(2), 986-1013. doi:

10.17583/generos.2016.1705

To link this article: http://dx.doi.org/10.17583/generos.2016.1705

PLEASE SCROLL DOWN FOR ARTICLE

The terms and conditions of use are related to the Open Journal System and

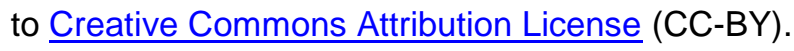


GÉNEROS -Multidisciplinary Journal of Gender Studies Vol. 5 No.2 June 2016 pp. 986-1013

\section{Becoming and Being a Women: Meanings and Values of Labial Elongation for Zambians in Cape Town}

Guillermo Martínez Pérez

Concepción Tomás Aznar

Universidad de Zaragoza
Mwenya Mubanga

Uppsala University

Brigitte Bangol

University of the Witwatersrand

\section{Abstract}

Zambian women might doubt whether to stop or preserve labial elongation, which is a female genital modification instructed to the girl child as the first rite of passage into womanhood. We conducted a grounded theory research among Zambian men and women who had immigrated to Cape Town. Twenty women and seventeen men participated. Beliefs and perceptions around womanhood, gender roles and pleasure place elongation as a practice that is highly valued by Zambians in South Africa. Interventions to promote and improve women's sexual health such as capacity building of healthcare professionals and design of information, education and communication materials can be informed by framing and documenting the implications for the Zambian migrant women's sexual and social wellbeing of this practice.

Keywords: Labia minora elongation; Zambia; Qualitative research; Female genital modifications; South Africa. 


\section{Devenir y Ser Mujer: Significados y Valores del Estiramiento de los Labios Menores para las Zambianas en Ciudad del Cabo}

Guillermo Martínez Pérez

Concepción Tomás Aznar

Universidad de Zaragoza

\author{
Mwenya Mubanga \\ Uppsala University
}

Brigitte Bangol

University of the Witwatersrand

\section{Resumen}

Las mujeres zambianas pueden dudar sobre si continuar o no la práctica de estiramiento de los labios menores. Esta práctica es una modificación genital femenina que se enseña a las niñas como uno de sus primeros ritos de paso hacia la edad adulta. Hemos realizado un estudio cualitativo, empleando la teoría fundada como marco metodológico, con inmigrantes zambianos en Ciudad del Cabo, en Sudáfrica. Veinte mujeres y diecisiete hombres participaron en este estudio. Las percepciones acerca de la madurez, feminidad, roles de género y de placer sitúan al estiramiento de los labios menores como una práctica que es altamente valorada por los zambianos en Sudáfrica. La elongación simboliza que una mujer es una 'zambiana propia' que ha sido instruida de acuerdo a roles de género validados por la sociedad. El investigar y documentar las implicaciones del estiramiento de labios menores para la salud sexual y social de las mujeres migrantes zambianas puede ayudar al diseño de intervenciones para promover y mejorar la salud de las mujeres - como por ejemplo mejorar el currículo de profesionales de la salud, o el diseño de materiales de información, educación y comunicación.

Palabras clave: Estiramiento de los labios menores, investigación cualitativa, Zambia; modificaciones genitales femeninas; Sudáfrica 


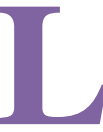

Abia minora elongation (LME) is a genital modification defined as "the expansive modification of the inner lips of the female external genitalia, or labia minora, by a process of elongating, with the help of a variety of herbs, oils, crèmes and other instruments" (Martínez Pérez, Tomás Aznar \& Bagnol, 2014). LME has been documented as a common practice along a crescent moonshaped corridor that covers most of East and Southern Africa (Bagnol \& Mariano, 2012; Grassivaro Gallo \& Catania, 2015; Mwenda, 2006; Pétursdóttir, 2010; Tamale, 2006). To some girls, LME is one of the first instructions they receive in a socialisation process that in many cases concludes with their attendance at initiation rituals into womanhood in which other instructions on personal hygiene, respect for elders and traditional ceremonies, and sexual techniques are provided (Pétursdóttir, 2010; Tamale, 2006; Martin Hilber et al., 2012; Rasing, 2001). The most common motivations given for the practice of LME are: to ensure marriageability, to become women, to feel feminine, and to enhance the sexual pleasure (Martínez Pérez, Tomás Aznar \& Bagnol, 2014).

South Africa is one of the countries to which Zambians migrate (International Organization for Migration, 2013). LME is practiced in Zambia (Dauphin-Tinturier, 2008; Mwenda, 2006; Rasing, 2001; Spring, 1973). In South Africa, LME is documented as having been practised by some women in the north-eastern provinces (Krige \& Krige, 1980; Manabe, 2010; Milubi, 2000). In Western Cape province, LME is no longer practised but was practised among some Khoi-San women in the past (Holmes, 2007; Qureshi, 2004). To date, no research has been done on Zambian migrants in South Africa and their health experiences with LME.

A systematic review of the health implications of LME reported that the procedure of pulling might involve some adverse effects such as pain, swelling, irritation or itchiness when passing urine (Martínez Pérez, Tomás Aznar \& Bagnol, 2014). This systematic review included research conducted in countries where LME is normative. There is a paucity of literature on how African women who have migrated to countries where LME is not practised perceive the role that LME plays in their sexual lives. The Working 
Group on Female Genital Mutilation of the University of Padua in Italy is an academic institution that has led research in various African regions and that has investigated the health implications of LME (Grassivaro Gallo \& Catania, 2015). This academic institution conducted a study in Italy among migrants who had practised LME and reported that some women had been offered cosmetic surgery to cut their elongated genitalia (Grassivaro Gallo \& Catania, 2015).

\begin{abstract}
Aim
This study follows the recommendation made by scholars from the Working Group on Female Genital Mutilation of the University of Padua to investigate the implications for the health of migrant women who have practised LME (Grassivaro Gallo \& Catania, 2015). The preparation of this study draws from the field of public health and medical anthropology, it has been led by a multidisciplinary team of social and health scientists, and it has the intention to collect and document information on populations' experiences with labial elongation to better inform design and implementation of culturally-acceptable public health interventions to protect and improve women's sexual health.

The purpose of our study is to explore Zambian migrants' perceptions and experiences towards LME, its meanings and values, and to explore its health risks and benefits. The specific aim of this article is to report the findings that relate to themes around femininity and womanhood, gender roles, and pleasure and erotica. A subsidiary aim is to discuss how the findings may help to inform interventions to promote women's sexual health. Another article reports on the findings that relate specifically to the physical and psychosocial health implications of LME as experienced by the women participants of this study (Martínez Pérez et al., 2015).
\end{abstract}

\title{
Methods
}

This study was conducted between December 2013 and May 2014 in Cape Town, Western Cape, South Africa. This was a qualitative study using constructivist grounded theory methodology (Charmaz, 2012) informed by a 
feminist perspective (Plummer \& Young, 2010; Wuest, 1995). Constructivist grounded theory suggests that there exist multiple realities that are constructed by people based on the meanings that they assign to the world around them, and it is an approach to qualitative research conduct that involves individuals and groups as active agents as co-generators of data, concepts, interpretations and theory through an interactive and iterative process guided by the field investigator (Charmaz, 2012). Additionally, feminist perspective helped for the principal investigator to practise reflexivity (a reflection on the investigator's impact in the research process), to pay attention to the impact of gendered-power imbalances in the research process, and to ensure that data and theory were co-constructed with the participants and that the findings of this study were useful for women's health and for social change (Plummer \& Young, 2010; Wuest, 1995). The Human Sciences Research Council (Pretoria, South Africa) granted ethical approval.

Zambian women and men above 18 years old who had lived in the Western Cape for at least one year were eligible. Women eligible must have practised LME. The participants were identified by snowball sampling (Bryant \& Charmaz, 2007). The first two individuals who directed the principal investigator (GMP) to other eligible participants were identified among the social network of one of our study co-investigators, a female Zambian (MM).

All participants were contacted telephonically to explain the purpose of the study. If interested in participating, a date for an in-depth interview (IDI) was scheduled. Before the IDI was conducted, written informed consent was sought.

All participants in the IDIs were offered the opportunity to take part in a natural group discussion (NGD). A NGD is a method for eliciting information from persons who naturally congregate together and can provide a shared perspective on a particular topic (Kielmann, Cataldo \& Seeley, 2012). All NGDs were single-gendered.

Two systematic reviews on LME informed an interview guide that was used during the IDIs and NGDs (Martínez Pérez, Tomás Aznar \& Bagnol, 2014; Martínez Pérez, Bagnol \& Tomás Aznar, 2014). Data collection happened in a private location of the participants' choice, and was led by the principal investigator. A female assistant interviewer accompanied the 


\section{Martínez-Pérez, Mubanga, Tomás-Aznar \& Bagnol-Being a Zambian Woman in South Africa}

principal investigator during the IDIs and NGDs with the women participants only. All data collection took place in English. IDIs and NGDs were tape-recorded. All recordings were transcribed verbatim.

Constructivist grounded theory guided the analysis process, in which memo writing, theoretical sampling, and line-by-line coding using gerunds were the measures employed (Charmaz, 2012). As per Charmaz's constructivist grounded theory, data collection and analysis took place contemporaneously whilst theoretical sampling assisted the adaptation of the interview guide with the aim of exploring all new emerging concepts (Bryant \& Charmaz, 2007). Data collection and analysis continued until saturation of the properties of the emerging concepts was achieved. At that point, recruitment of participants was stopped.

Different measures were taken to ensure trustworthiness of this study (Shenton, 2004). The findings from the IDIs and NGDs were triangulated with the literature on LME in Zambia. The main findings from the IDIs were shared with some of the participants in the NGDs (member checks). All interpretations made by the principal investigator of the study findings were cross-checked for cultural appropriateness by our Zambian co-researcher. In reporting the findings of this study, we used participants' own expressions and we included analysis of deviant cases. In the Results section of this article, expressions used by the participants are in italics.

\section{Results}

Twenty women and seventeen men participated (Table 1). Only two men refused to participate. All participants took part in an IDI. Three NGDs with 14 women and two NGDs with seven men were conducted. The mean age was 32 years for both women and men. The women had lived in South Africa 6.6 years on average and the men 4.9 years. There was balanced representation of married and single participants among women and men. With regards to their education, half of the participants held college and university degrees, while one woman had completed primary studies only. Bemba was the ethno-linguistic affiliation that most participants belonged to (11 women and six men). 
GÉNEROS-Multidisciplinary Journal of Gender Studies, 5(2) 992

Table 1.

Characteristics of study participants.

\begin{tabular}{|c|c|c|c|c|c|c|c|c|c|}
\hline $\begin{array}{l}\text { IDI* } \\
\text { Nb: }\end{array}$ & Sex & Pseudonym & Age & $\begin{array}{l}\text { Years } \\
\text { living in } \\
\text { Cape } \\
\text { Town }\end{array}$ & Married & $\begin{array}{l}\text { Highest } \\
\text { level of } \\
\text { educatio } \\
n\end{array}$ & Profession & Tribe & $\begin{array}{c}\text { NGD* } \\
\mathrm{Nb}\end{array}$ \\
\hline 1 & $\begin{array}{l}\text { Wome } \\
n\end{array}$ & Sarah & 33 & 13 & Divorced & $2^{\text {ary }}$ & $\begin{array}{l}\text { Nurse } \\
\text { assistant }\end{array}$ & Nyanga & $\begin{array}{c}\text { NGD\#1 } \\
\text { ، }\end{array}$ \\
\hline 2 & & Yvonne & 32 & 4 & Single & $2^{\text {ary }}$ & Unemployed & Bemba & “ \\
\hline 3 & & Rita & 34 & 8 & Married & Univ. & Social worker & Bemba & “ \\
\hline 4 & & Linda & 30 & 6 & Single & Univ. & Social worker & Bemba & “" \\
\hline 5 & & Paula & 29 & 3 & Single & College & Hotel manager & Bemba & “ \\
\hline 6 & & Rose & 32 & 8 & Married & College & Accountant & Bemba & \\
\hline 7 & & Lucy & 32 & 1 & Divorced & College & $\begin{array}{l}\text { Inform } \\
\text { Systems }\end{array}$ & Tonga & $\begin{array}{c}\text { NGD\#2 } \\
\text { ، }\end{array}$ \\
\hline 8 & & Bertha & 23 & 7 & Single & $2^{\text {ary }}$ & Student & Lozi & “ \\
\hline 9 & & Juliette & 32 & 10 & Single & Univ. & Social worker & Bemba & \\
\hline 10 & & Harriet & 30 & 5 & Married & 2ary & Waitress & Bemba & NGD\#3 \\
\hline 11 & & Tandi & 46 & 2 & Single & Univ. & Lawyer & Bisa & “" \\
\hline 12 & & Julia & 26 & 4 & Married & College & Student & Nsenga & “" \\
\hline 13 & & Enia & 38 & 10 & Single & $2^{\text {ary }}$ & Cashier & Nyanja & “" \\
\hline 14 & & Ann & 34 & 10 & Married & $1^{\text {ary }}$ & Cook & Nsenga & “ \\
\hline
\end{tabular}


993 Martínez-Pérez, Mubanga, Tomás-Aznar \& Bagnol-Being a Zambian Woman in South Africa

\begin{tabular}{|c|c|c|c|c|c|c|c|c|c|}
\hline $\begin{array}{l}\text { IDI* } \\
\mathrm{Nb:}\end{array}$ & Sex & Pseudonym & Age & $\begin{array}{l}\text { Years } \\
\text { living in } \\
\text { Cape } \\
\text { Town }\end{array}$ & Married & $\begin{array}{l}\text { Highest } \\
\text { level of } \\
\text { educatio } \\
n\end{array}$ & Profession & Tribe & $\begin{array}{c}\text { NGD }^{*} \\
\mathrm{Nb}\end{array}$ \\
\hline 15 & & Lucy & 38 & 1 & Married & Univ. & Public health & Bemba & NO NGD \\
\hline 16 & & Alice & 27 & 4 & Married & Univ. & HR/Admin & Bemba & 6 \\
\hline 17 & & Maria & 54 & 20 & Divorced & Univ. & Social worker & Tonga & “ \\
\hline 18 & & Helen & 25 & 2 & Single & $2^{\text {ary }}$ & Hairdresser & Bemba & 6" \\
\hline 19 & & Caroline & 27 & 4 & Married & $2^{\text {ary }}$ & Cook & Bemba & “ \\
\hline 20 & & Rebecca & 36 & 10 & Single & $2^{\text {ary }}$ & Hairdresser & Nyanja & \\
\hline 21 & Men & Josuah & 41 & 10 & Married & Univ. & Accountant & Bemba & NGD\#4 \\
\hline 22 & & John & 35 & 3 & Single & Univ. & Engineer & Lozi & “ \\
\hline 23 & & Peter & 43 & 15 & Married & Univ. & Accountant & Tumbuka & “ \\
\hline 24 & & Brett & 23 & 1 & Single & Univ. & Engineer & Nsenga & “ \\
\hline 25 & & Carl & 35 & 3 & Married & Univ. & Chemist & Tonga & “ \\
\hline 26 & & Rod & 24 & 5 & Single & $2^{\text {ary }}$ & Sales & Lunda & NGD\#5 \\
\hline 27 & & Simon & 25 & 2 & Single & $2^{\text {ary }}$ & Security & Lunda & “ \\
\hline 28 & & Sam & 22 & 1 & Single & $2^{\text {ary }}$ & Cashier & Lunda & “" \\
\hline
\end{tabular}


GÉNEROS -Multidisciplinary Journal of Gender Studies, 5(2) 994

\begin{tabular}{|c|c|c|c|c|c|c|c|c|c|}
\hline $\begin{array}{l}\text { IDI* } \\
\mathrm{Nb}:\end{array}$ & Sex & Pseudonym & Age & $\begin{array}{l}\text { Years } \\
\text { living in } \\
\text { Cape } \\
\text { Town }\end{array}$ & Married & Studies & Profession & Tribe & $\begin{array}{l}\text { Took part } \\
\text { in NGD } \\
\text { Number... }\end{array}$ \\
\hline 29 & & Armand & 36 & 1 & Married & Univ. & Lawyer & Mambwelongwe & NO NGD \\
\hline 30 & & Matt & 30 & 3 & Single & Univ. & Engineer & Bemba & 6 \\
\hline 31 & & Tom & 28 & 2 & Married & Univ. & Sociologist & Ngoni & “ \\
\hline 32 & & Marc & 38 & 6 & Single & College & Nurse & Mwanga & “ \\
\hline 33 & & Will & 39 & 7 & Single & College & Accountant & Bemba & 6 \\
\hline 34 & & Angel & 37 & 9 & Married & College & Hotel & Nsenga & “ \\
\hline 35 & & Jon & 32 & 7 & Married & Univ. & Banker & Bemba & "6 \\
\hline 36 & & Alek & 32 & 7 & Married & Univ. & Sociologist & Bemba & \\
\hline 37 & & Paul & 36 & 2 & Married & Univ. & Economist & Bemba & \\
\hline
\end{tabular}

IDI* The 37 participants were in-depth interviewed. All individual interviews took place before the NGDs.

NGD* Those participants who knew no one other than the individual who had identified him or her as a potential eligible participant in the study did not take part in any NGDs. 


\section{Becoming a Proper Zambian Woman}

All women had been asked to comply with kudonza (pulling) before they had their first menstruation. Pulling was the first of a series of rites of passages essential for a woman to be granted the status of a proper Zambian woman. Because, traditionally, mothers did not discuss sexual matters with their daughters, as girls, the female participants had been referred to another female elder for instruction. The majority of the female participants said that, at that young age, they were asked to comply with LME to become a woman and also to ensure their marriageability.

One of the main motivators for achieving malepe or imishimo (pulled labia) was to enhance the sexual pleasure of the male partners. However, this reason was not disclosed to the young girls. A few women said that they only found out about this motivation at a later age. The following excerpt represents a deviant case: that of a woman who was informed of the role that LME played in sexual intercourse before she had her first menses:

Bertha: When I was 12, I visited my cousin. She showed me when you are supposed to pull them. She did not really tell me the reason why... So after that I visited my grandmother and she told me; 'You pull them because your husband would expect you to have them, and in marriage you have to have them... And usually in sexual interaction is when he would be feeling them. So if you don't have he might send you to your parents and say that; 'She hasn't been taught'

Pain, irritation, soreness, itching when passing urine and swelling were mentioned as potential adverse events of pulling. These harmful side effects could take place at the start of pulling, and also when girls used pegs or herbal stems to clamp the labia to force them to stretch. To aid the process, some girls used various umuthi (herbs) that the girls pounded, roasted and mixed with Vaseline or other creams. Some herbs were stinging and caused inflammation of the labia. It was commonly agreed that most of the potential discomfort was minor, bearable, and preventable if the girls followed certain hygienic measures.

The women participants explained that no girl would think that the elder instructors meant them any harm. The elder's role was to promote a 
procedure perceived to be a tradition yielding benefits in marriage and sexual life. Zambian girls respected the wisdom and authority of their elders. Hence, no woman recalled having bluntly opposed the elders' advice:

Juliette: There is a certain plant... We call it impwa [shrub], similar to an eggplant. It is small, but more whitish or greenish. It is very bitter... And I remember once I tried that, and my labias just became so swollen and sore and very painful. And I was scared! But that did not stop me from doing what I think was the right thing, because that was coming from my parents, my grandmother, and everyone else has been doing it and it has been proven to be working for the people.

Girls learned to behave as women-to-become in groups that gathered to kusowe (to play, meaning to elongate). Some girls felt excited to be part of a collective exercise of becoming women in which social and friendship bonds were formed. On the other hand, such was the power of peer influence that some women recalled that they felt forced to pull:

Lucy: I think it was exciting because every one of my age was doing that. If you didn't do that you were like: you don't know anything! You just have to do it, it was... We used to encourage each other. Sometimes I practised in groups. But mostly when I was by myself. And when I go to my friend I liked to see if I had better than them.

Girls competed as to how far they had gone in achieving the desired 1.5 to 2 inches. Those who had succeeded received words of appreciation from their peers. With the exception of one participant who said that she had experienced sexual pleasure during kusowe, the majority of women stated that mutual pulling did not aim to provide pleasure to each other but to ensure that the lazy girls achieved malepe:

Rose: When it comes to sexual feelings, it is only when you meet a man. That is all what we believe. Even the time we did that, even when we experience maybe one or two girls that have ended up maybe masturbating themselves, or anything... no, not at all. It never used to happen that way. 


\section{Martínez-Pérez, Mubanga, Tomás-Aznar \& Bagnol-Being a Zambian Woman in South Africa}

The secret behind pulling was often revealed by the banachimbusa (women who know), during the initiation rites to which some of the women were sent after their first menses. During cisungu (the initiation rites), the youth passively learned how to become women. At cisungu, the importance of practising kudonza for marriage and sexual life was emphasised by the banachimbusa. The women explained that one benefit of kudonza was that it enhanced sexual pleasure because the elongated labia wrap and hold the penis, as if the elongated labia were curtains or covers, thus preventing the penis from coming out of the vagina during intercourse. The male participants expressed the same belief about the function of the malepe of holding the penis during intercourse. This excerpt exemplifies how one woman disregarded this common belief:

Linda: We were told that those things hold the penis. That was the main purpose of pulling. But I have never heard of somebody who has never pulled saying that the penis is not able to hold... I think whether you pulled or not, you are still the same; the penis will still be there.

At cisungu, the young women received other instructions on the intricacies of marriage and sexuality, including additional practices that their male partners could expect them to have learned, such as the use of waist bead belts or the dancing skills in bed, shaving each other's pubic hair, or washing the husband's penis after intercourse. In this study, many men and women disagreed that young girls received such instructions. With the aim of protecting the young girls against any potential harm, some women and men suggested that both mothers and fathers should challenge traditional roles regarding the passage of information and become instructors on sexual and reproductive matters - kudonza included. Some of the men, particularly those who considered the practice of kudonza no longer necessary, focused more on encouraging them to appreciate their own bodies:

Armand: I love my daughter and I would take responsibility to the extent that I could talk to her about some of these issues. Probably in the presence of her mother... I think... it [pulling] takes away the dignity of a woman, to have to go to all these lengths to elongate themselves. It is like telling a man; 'you must elongate your penis in 
order to satisfy a woman'... I would not want that [pulling] to cloud the sexuality of my daughter. I would want her basically to feel adequate as she is and without having to go through all that discomfort and potential risk associated with [pulling].

\section{Being a Proper Woman}

Many women, before marriage, had their genitalia checked. According to one participant, when lobolo (bride price) was given, the groom expected to know whether the bride had pulled. Most often, the women were just queried on their compliance with kudonza. If they had complied, the relatives and/or the grooms were informed that she was ready for marriage. Many women, during their childhood, feared that if they had not achieved malepe, the marriage could be cancelled, return of lobolo requested, and their own female relatives embarrassed, as they could be perceived as not having raised the bride properly according to tradition:

Alice: You have premarital counselling at church. And premarital counselling traditionally. They prepare you for your traditional role as a wife; what you are supposed to be doing in the house, doing for a guy, maybe receiving in-laws... They also touch on whether you had pulled or not. So I was asked; 'Did you pull?' And I said; 'Yes'. And they said; 'That is fine'. But I had some of my colleagues who said; 'Yes, I have,' and they; 'Can we check it?'

Zambian men had the expectation that their wives had malepe. For a traditional Zambian man, not seeing malepe might signal that the wife was not woman enough. Absence of malepe might suggest that the wife had not been trained in other aspects that men expected in terms of enhancement of sexual satisfaction, keeping virginity until marriage, showing respect to their authority as breadwinners and providers, and having developed the skills to take care of the household and raise the children.

Many women stated that failure to pull could lead a dissatisfied partner to seek out other female partners. To some women, even if their partners were seeking sexual affairs, having practised LME ensured that the men would always return to their wives. 
Some women considered kudonza as a waste of time now because, according to them, more progressive men, who no longer demand the stereotypical traditional Zambian type of woman, would not appreciate the effort a woman has gone to in order to succeed with pulling. A few perceived a gender imbalance in the fact that they were expected to endure genital modification practices, while the men were not subjected to the same social pressure to modify their bodies to fulfil women's expectations:

Alice: How many things are we going to do to be considered women? Ay, no! The men just stay put, grow up, pass through puberty, and ah! Life goes on. And here [in Zambia] they tell them what to expect from this woman, so you are forced to pull these things, yeah, slave away in the home and the man is... no, I don't think it should be encouraged!

One reason to disregard pulling is that, to some women, if there were romance in the relationship, their partners would accept them regardless of the appearance of their genitalia. Many men shared a similar opinion; friendship and companionship were viewed as critical in establishing a bond with a partner. Despite appreciating these other components in their romantic relationships, most women and men participants defended the social discourse that dictates why pulling should be continued: it ensures that a woman is considered a proper Zambian woman because malepe symbolised that her upbringing was conducted in accordance with socially condoned gender roles.

\section{Being a Provider}

The participants said that women are tagged as receivers and men as providers in Zambia. Traditionally, women were expected to take care of their homestead and offspring while men were expected to provide food, security and financial means. However, some women and men described how these roles changed hands when women perform as providers of sexual pleasure (by means of having practised LME) and men as receivers of their partners' customised genitalia and also of the sexual skills that the women had been taught at cisungu. Some women explained how as girls they were 
disciplined to fit into a gendered role in which they were to comply with a multi-tasked position in their marriages:

Tandi: Being a woman, I am a provider. Of passion, love, making feel a man very secure because in my own culture there are five things that I had been told: a woman has to be a man's friend, his girlfriend, his bitch, his wife, and most of all, his sister. Being a wife, you have to look after him from head to toe. Don't talk rubbish; listen, be a provider, whatever, and be good in bed, the most important thing is being good in bed. Give him as more as he likes... And being a mother; you have to understand him. Look at him, 'his emotions are crazy now, what I am going to say?...' Don't leave him alone. Don't set him free to go and look for something else. That is when you become a mother. Being a girlfriend you have to be there, have fun with him. Now being a bitch, maybe he wants to do crazy stuff in bed! But you do it! Or you go and imagine other stuff and give it to him.

As mentioned above, social pressure on all women to fit into the role of pleasure-enhancers in their marriages began in pre-adolescence when they were guided into the practice of kudonza. By contrast, the men were not instructed to fit into a similar role by any male elder. No men said that their role as providers of sexual pleasure for the women was ever emphasised during their upbringing.

Traditionally, women were not supposed to initiate sex. However, these attitudes might have changed today as most women claimed that they could now ask their partners for foreplay with their elongated labia. A few men indicated that they appreciated more open communication on sexual matters. To other men, however, it was odd to hear their partners demand from them certain sexual practices. The men might think that the women had actually been learning that from outside while cheating on them.

As adults, women and men perceived that one of the most beneficial purposes of pulling is to enhance pleasure for both partners. Men were said to fondle the malepe before intercourse. Most women said that they felt aroused during foreplay, and this was something that made them feel that kudonza was a beneficial practice:

Caroline: When you have got them, they like it. Some they like to play with them... Ok, I'm gonna say! If you are in bed, there are some 


\section{Martínez-Pérez, Mubanga, Tomás-Aznar \& Bagnol-Being a Zambian Woman in South Africa}

things that they like... there is a blow job, sucking each other, our men they like to suck that [the labia] also, it is like part of them also. To lick them. And they like to play with it before sex. It turns them high. Interviewer: It turns you high as well?

Caroline: Yeah! Yeah, it is also good for women.

Oral sex on the malepe was part of foreplay according to some female and male participants. However, traditionally, oral sex was taboo. One woman said that; 'Zambian men, they do not like oral sex, they say they can never lick a woman'. Her statement agreed with the following excerpt from a male participant:

Will: ...in our tradition it is taboo. You even find that in a marriage, when you are practising oral sex, then so happens that one of you dies. Then you have to report that to the elders, that; 'We used to have oral sex' And there is a belief that if you did oral sex and you did not disclose it, after your spouse is dead, then something might happen, and then eventually in a short period of time you also die.

Foreplay with the elongated labia was explained as necessary, before intercourse, to prepare the body of the woman and ultimately lead to sexual satisfaction and conception. In this excerpt this woman explained how tradition paralleled the act of sex with the act of cooking in the home hearth:

Paula: In the olden days they used to believe, a long time ago, they used to cook in the firewood, they used to say; 'When you pull the pot, you cannot put the pot straight on the fire, you must put stones' So they also took that as in the house, as when the husband is having sex with you, they believe that the penis must hold, it is like the labias hold the penis and he feels the satisfaction.

Only one woman said that she used to masturbate, in the absence of her male partner, and that her elongated labia helped her to get aroused. One man appreciated that his girlfriend has malepe and can masturbate instead of seeking for other men while he is travelling for work. To the majority, however, autoerotism was not acceptable: 


\section{GÉNEROS -Multidisciplinary Journal of Gender Studies, 5(2) 1002}

Bertha: I never used to masturbate. If I want to have sex I go to my boyfriend and tell him, or call him and say; 'I want to have sex,' and he would say; 'Ok, you can come by my place,' and then I go. Cause playing with it... I would want to have that feeling of a man inside me.

\section{Conflicting with Religious Values}

Conversion to Christian religion played a role in some Zambians reanalysing the need to preserve pulling in South Africa. Some participants of both sexes thought that female youth should be encouraged to accept their bodies and that they need not engage in any genital modification:

Marc: God created human kinds in his own image, so that thing is not acceptable because you are against the Bible, [against] what God said. God has created the human being. He has created him with all the feelings, with all the equal parts, so there is nothing that [says that]; 'This is short so I am not gonna satisfy my partner,' or [that says that]; 'If this is long I am gonna satisfy my partner.'

The participants were asked if the practice of pulling conflicted with their religious values. All women and men responded that they had never heard of any religious leader in Zambia or in South Africa advocating to stop pulling. As one man explained, the reason why pulling does not conflict with religious values is:

Jon: The Bible puts it clear that the woman is to warm the home, and the home is not the home without a man. So the woman must do anything possible to keep the man at home. Obviously, if he is getting whatever he wants from a woman, I don't think he'll go out there and look for somebody else. So our women are actually taught how to keep their men. Cause if this men really likes the labia elongated, and the wife doesn't have it, obviously they would be sleeping around.

Having malepe helped the majority of women to feel more satisfied with their bodies. Kudonza was perceived as one more component of beautifying oneself, not much different than other body embellishments, which did not conflict with their Christian values: 
1003 Martínez-Pérez, Mubanga, Tomás-Aznar \& Bagnol-Being a Zambian Woman in South Africa

Juliette: The Bible does not say anything about making the labias long. Those are things that a person does, for example earrings... So why they say it is unchristian?... I think if a person can put a weave, and can plait, wear certain clothes, paint the nails... This is the same as pulling your labias. It won't make you less a Christian. You are just trying to look after yourself. Making yourself ready for marriage.

\section{Enacting 'Zambianness' in Diaspora}

The participants were asked to elaborate on how living in South Africa might have influenced their perspectives on pulling, and how South Africa might have influenced their opinion on seeing the new female generations which included their own daughters- instructed in the procedure of labial elongation. Commonly, South Africa was perceived as a different culture, comprising a complex conglomerate of Blacks, Coloureds, Whites, and people from many other nationalities, but with common cultural traits to Zambia, namely payment of lobolo (bride price), presence of sangomas (traditional healers) and use of umuthi (traditional medicines). South Africans were perceived as Westernised people who had lost their traditional values. The participants' specific perceived advantages of Cape Town were freedom of expression and movement; the more balanced gendered roles and norms; law enforcement to protect women against abuses; and a general sense of social respect to sexual minorities and different lifestyles.

Most participants stated that living in South Africa had not played a role in them modifying the values of kudonza. Whilst in South Africa, the participants preferred to uphold Zambian traditions that they identified as beneficial - such as LME - and disregard the practices that they perceived as prejudicial.

Peter: It has to be Zambian way. I cannot live like a South African. I am not! So if I go to America, do I have to live like an American? No. Never. You are a Zambian, whether you change your citizenship. People are exposed to anything... people are exposed to Satanism, you have to join? People are exposed to gay, do you have to join? No. It is individual. Me, I have chosen to maintain my Zambianness. 
Invariably, the ones that believed that pulling should be discontinued said that they had that mindset before arriving in South Africa. Women's views very much depended on their personal experiences with pulling when they were young as well as on the reactions of either appreciation or indifference from their male partners. Acknowledgement of other men holding different preferences with regards to sex and genitalia made some women disregard the importance of kudonza. Four women who said they had dated South African, Congolese, Nigerian and German men said that they understood now that not all men require women to have pulled.

Self-awareness of their otherness was also described when women had to attend consultations in South African health facilities. Though most had not actually encountered any health personnel who made uncomfortable comments, a few recalled stories of doctors offering to cut the elongated labia of other Zambian women.

Some women explained that they discussed at the ladies' meetings (church lay women's groups) whether they should transmit the tradition of labial elongation to the young Zambian girls in South Africa. Regardless of their personal experience with pulling, some women thought it appropriate to tell their daughters, and let them make their own choices. They aimed to protect themselves against their daughters blaming them for not complying with their role as parents, as keepers of tradition.

Most participants claimed that they would appreciate it if new generations agreed to continue the tradition. However, this appreciation did not mean that the participants did not discuss the currency of the traditional rationale behind pulling. For instance, the majority perceived kudonza as a practice that enhanced the sexual pleasure of both women and men. However, some participants thought that the admiration towards kudonza would diminish if young people received appropriate sexual education and learned that sexual pleasure might also be enhanced in different ways other than by fondling the malepe. All men with a university education held the opinion that pulling could be discontinued as it did not have the social significance that it had in the past. This excerpt exemplifies the perceptions of one participant who, though having previously admitted how beneficial kudonza was for herself, had now stopped valuing its relevance:

Interviewer: You think girls in Zambia should stop? 
1005 Martínez-Pérez, Mubanga, Tomás-Aznar \& Bagnol-Being a Zambian Woman in South Africa

Harriet: Yeah! Because that time that we wasted to pull all those things, you can do other things like maybe studying or learning about HIV/AIDS... And also men won't choose 'this woman with this' cause other countries do not have; 'This woman with this, not this woman...' I think all the women must be the same.

All participants agreed that, today, pulling was a very entrenched practice that was described as too secret and at the same time too socially condoned to be openly discussed and confronted in Zambia. As one woman expressed, social pressure to comply with pulling was such that women needed to practise it to protect their self-esteem, which in part depended on how their public image as proper women was perceived:

Juliette: [The women who have not pulled] even feel they have low self-esteem if they find themselves in a context where each and every woman has them. Even in Lusaka, the capital... even the most educated people in Zambia, even the president's wife has to have them! Truly, if you don't have them; Why are you being called a woman? A proper woman?

Among the ones who viewed pulling as irrelevant, it was believed that it could not be stopped in Zambia unless more information on its health implications was generated. It was thought that, due to the social discourse defending pulling in Zambia and among Zambians in South Africa, a very bold move to stand up and talk against this specific tradition was necessary:

\begin{abstract}
Alice: I do regret that I even tried to start, because I think it is absolutely nonsense and we shouldn't even deal with it, but of course I cannot say this to some of my colleagues because some of them would look as if I am being silly or because I have a bit of an education I disregard certain traditions or cultures or beliefs...
\end{abstract}

\title{
Discussion
}

This study demonstrates that LME is a genital modification that is highly valued by some Zambian migrants because it is perceived as a beneficial practice for their social and sexual wellbeing. Traditionally, LME is valued 
because it symbolises that a woman has received all instruction necessary to fit into the roles in marriage and in sexuality that local norms dictate. To become a 'proper Zambian woman', all young girls are expected to practice elongation and achieve malepe so their male future male partners can appreciate the type of education they received during their upbringing. Traditionally, according to some Zambian, being born with female genitalia is not sufficient: young girls must undergo a series of rituals, instructions and body modifications for them to gain the social and gendered status of 'true women'. These findings support other evidence provided by qualitative inquiry on LME in, to name a few research sites, Malawi (Pétursdóttir, 2010), Mozambique (Bagnol \& Mariano, 2012), eastern DRC (Grassivaro Gallo \& Catania, 2015) and Uganda (Tamale, 2006).

The strength of this study lies in the exploration of the views on LME for Zambian migrants in South Africa -a context where pulling is not customary- and the insights gained as a result into how women and men might agree or dissent the social discourses on their own traditional genital modifications. In general, there was resistance among the participants to identify living in South Africa as a factor that might have changed their perspectives on LME. Acceptance of one's body as dictated by Christian thinking, and also social and sexual contact with Africans from countries other than Zambia shaped some of the influences that had an imprint on the values given to LME. The participants placed themselves as the others who practise kudonza and who perceived the South Africans as Westernised and culturally distinct. In the absence of evidence on the health implications associated with some of their traditional practices, in South Africa some participants argued that they consciously upheld those traditions - such as LME - that they perceived as contributing positively to their wellbeing and that could help them to enact what being a proper Zambian involves.

This study drew from recommendations made by scholars from the Working Group on Female Genital Mutilation of the University of Padua to study the implications of the health of migrant women who live in countries where LME is not customary (Grassivaro Gallo \& Catania, 2015). According to research conducted by the Working Group on Female Genital Mutilation of the University of Padua, women migrants from LMEpractising countries living in Italy might face prejudice from their sexual partners (Grassivaro Gallo \& Catania, 2015). No similar evidence was found 


\section{Martínez-Pérez, Mubanga, Tomás-Aznar \& Bagnol-Being a}

Zambian Woman in South Africa

in our study; prejudice from sexual partners was not a matter of concern that any Zambian woman expressed.

In this study, a few women said that they knew of other Zambian women who had met South African doctors who offered to $c u t$ their elongated labia. This finding supports previous research in Italy (Grassivaro Gallo \& Catania, 2015) and in Norway (Johansen, 2006) that reported that women migrants might encounter clinical practitioners offering them labiaplasty. In these situations, there might be a power imbalance in which migrants could be subjected to the mastery of South African health personnel. Nevertheless, due to the small sample of this study, it is recommended to analyse further how Zambian women, regardless of whether they reside in their home country or abroad, experience and develop coping mechanisms as a response to their exposure in different environments to men and women who advise them on the alteration of their genitalia to meet local norms.

A limitation of this study is transferability (Sikolia et al., 2013). Living in Cape Town, where freedom of expression was appreciated by the participants, might have contributed to the Zambians' articulation of their emic perspectives on LME in the frame of academic research. We should be circumspect about whether the same discourses would result if our study were replicated in Zambia. Further research should be carried out to verify if the meanings and values than emerged from this study in Cape Town could be generalised to other populations from LME-practising countries.

\section{Contribution to Women's Sexual Health}

This study contributes to framing how Zambian migrants experience LME. Zambian migrants might defend and preserve labial elongation if they perceive that this practice brings social recognition to the women and that it contributes to the enhancement of the sexual pleasure of both male and female partners. Understanding the sexual preferences and expectations of different populations across the world might help inform design and implementation of interventions to promote and protect women's sexual health (Collumbien et al., 2012). Based on the findings that we present in this article, we argue that the knowledge on LME that we co-generated with our participants could help to inform capacity-building in culturally- 
congruent care for South African healthcare providers as well as design of information, education and communication (IEC) materials.

Most labour migrants in South Africa arrive from neighbouring Southern African Development Community countries such as Zimbabwe, Mozambique and Lesotho (International Organization for Migration, 2013), all countries where some women practise LME (Martínez Pérez, Tomás Aznar \& Bagnol, 2014). Understanding of values that Zambian and other African women place on LME could assist South African healthcare providers to learn about this specific practice. Many women who have practised pulling could benefit from receiving culturally-congruent care by gynaecologists, midwives and nurses who are knowledgeable about LME. The promotion of sexual health might be more efficiently operationalised if healthcare professionals were aware of the evidence-based knowledge on LME as a practice that has been reported by many women as beneficial to their own social and sexual lives (Martínez Pérez, Bagnol \& Tomás Aznar, 2014). Promotion of sexual health requires a respectful approach to sexuality and its multiple manifestations, and healthcare providers should consider migrant women's preferences towards having free-of-coercion, pleasurable and safe sexual experiences (Edwards \& Coleman, 2004). Acknowledgement that, to many Zambians, kudonza positively contributes to both partners' sexual pleasure might prevent African women in diaspora facing situations where clinicians offer to surgically remove the elongated labia or where women feel misunderstood by healthcare professionals who can reasonably be expected to attend the sexual and reproductive health needs of female patients.

On the other hand, healthcare providers should also take into account that there are some African women who have expressed that LME is a painful experience to them and who disagree with the belief that LME enhances women's sexual pleasure (Martínez Pérez, Tomás Aznar \& Bagnol, 2014; Martínez Pérez, Tomás Aznar, Tomás Aznar, 2014). These women might also benefit from appropriate culturally-congruent care that meets their care needs while in diaspora, provided by professionals who are knowledgeable of the procedure and potential adverse effects for women's health of LME.

Sengendo and Sekatawa (1999) identified labial pulling as one of the cultural tenets in Uganda whose association with HIV transmission must be further investigated. Adeokun Twa-Twa, Ssekiboobo and Nalwadda (1995) 
1009 Martínez-Pérez, Mubanga, Tomás-Aznar \& Bagnol-Being a Zambian Woman in South Africa

and Grassivaro Gallo (2015) suggested that instruction on LME might encourage young girls to seek sex and hence risk HIV infection. Evidence from qualitative research from Mozambique (Chilundo et al., 2005) and from Uganda (Pool et al., 2000) indicated that some men may refuse to use a female condom in order to have access to the lengthened labia of their partners. The fact is that, to date, no quantitative study has been conducted to measure if there is any statistically significant association between HIV and labial elongation (Martínez Pérez, Tomás Aznar \& Bagnol, 2014). Furthermore, from the findings of this study in Cape Town, we lack evidence to state that labial elongation either increases or decreases risk of HIV. However, we assert that acknowledging the role played by LME in pleasure, desire and eroticism might be helpful to the preparation of IEC materials to prevent HIV transmission.

IEC materials that target Zambian female and male migrants must be culturally appropriate and include information conveyed in their language, representations, beliefs and value systems. Knowledge of gender norms that dictate how women's genitalia should be moulded to meet societal expectations and the corresponding men's sexual preferences can be taken into account to make communication in IEC strategies effective towards adoption of health-seeking behaviours such as use of HIV-prevention technologies. To help populations to prevent HIV, public health strategies should place more emphasis on sex-positive or pleasure-focused approaches to eroticise safer sex (Knerr \& Philpott, 2011). As an example, a Senegalese non-governmental organisation, to promote female condoms, has linked the noise made by thrusting into the condom during intercourse with the rattling of the waist bead belts (Knerr, 2008). Based on the findings of this study, and following a pleasure-focused approach, illustrations in IEC materials that aim to teach Zambians how to put on a female condom might consider depicting women's genitalia with their labia elongated. This might help people to feel confident that their sexual pleasure enhanced by the wrapping and holding effect of the malepe could be safeguarded when using a female condom. 


\section{Conclusion}

In this grounded theory study, most women and men defended and, at the same time, questioned the traditional values of LME. Pulling, as a symbol of adherence to traditional gendered values and norms, has contributed to improving some Zambian women's social and sexual relationships and, to some women, pulling had positively impacted their sense of femininity and womanhood. Many of our study participants would like this tradition to be preserved. However, it was acknowledged that motivations might have changed, and that Zambian people might hold different attitudes towards tradition, have different sexual preferences, and be less eager to comply with rites that are no longer believed to be meaningful. Future research should determine if the interventions to promote women's sexual health that we recommend, as informed by our study findings, might apply in a real scenario in Zambia, where social pressure for the adult women and female youth to comply with LME might be more fervently enacted than for Zambian women in diaspora. Future research in either Zambia or among Zambians in countries where LME is not normative should also comprise quantitative methodologies to more precisely the prevalence, frequency and procedures of labial elongation as well as its impact in the social and sexual health of women and their sexual partners.

\section{References}

Adeokun, L.A., Twa-Twa, J., Ssekiboobo, A., \& Nalwadda, R. (1995). Social context of HIV infection in Uganda. Health Transition Review, 5, 1-26.

Bagnol, B., \& Mariano, E. (2012). Gender, sexuality and vaginal practices. Maputo, Mozambique: DAA, FLCS, UEM.

Bryant, A., \& Charmaz, K. (2007). The SAGE Handbook of Grounded Theory. London, UK: SAGE Publications Ltd.

Dauphin-Tinturier, A. M. (2008). Pleasure and body adaptation. An approach to gender in Northern Zambia. In C. Zabus (Ed.), Fearful Symmetries: Essays and Testimonies around excision and circumcision (p. 77-95). Amsterdam \& New York; Rodopi. 
1011 Martínez-Pérez, Mubanga, Tomás-Aznar \& Bagnol-Being a Zambian Woman in South Africa

Charmaz, K. (2012). The power and potential of grounded theory. Medical Sociology Online, 6, 15p.

Chilundo, B., Mariano, E., Cliff, J., August, O., Palha de Sousa, C., \& Breslin, L. (2005). Trabalhadoras do sexo respondem ao HIV/SIDA: Segunda avaliação de intervenção da Organização da Mulher Educadora do SIDA (OMES). Maputo, Mozambique: Burnet Institute.

Collumbien, M., Busza, J., Cleland, J., \& Campbell, O. (2012). Social science methods for research on sexual and reproductive health. Geneva, Switzerland: World Health Organization.

Edwards, W.M., \& Coleman, E. (2004). Defining sexual health: a descriptive overview. Archives of Sexual Behavior, 33, 18995.

Grassivaro Gallo, P., Catania, L. (2015). Modificazioni espansive dei genital femminili, tra eredità e ambiente. Africa: passage di età attraverso il rito. Lungavilla, Italy: Edizioni Altravista.

Holmes, R. (2007). The Hottentot Venus. The life and death of Saartjie Baartman. Jeppestown, South Africa: Jonathan Ball Publishers.

International Organization for Migration. (2013). The well-being of economic migrants in South Africa: health, gender and development. Working paper for the World Migration Report 2013. Geneva, Switzerland: International Organization for Migration.

Johansen, E. (2006). Sculpted Female Bodies: Discourses and Practices on Genital Manipulation in the Context of Globalisation. Presented at Nordic Africa Days conference, The Nordic Africa Institute, Uppsala, Sweden, 30 September-2 October.

Kielmann, K., Cataldo, F., \& Seeley, J. (2012). Introduction to qualitative research methodology: a training manual. United Kingdom: Department for International Development (DfID).

Knerr, W. (2008). The global mapping of pleasure. Oxford, UK: The Pleasure Project.

Knerr, W., \& Philpott, A. (2011). Strange bedfellows: bridging the worlds of academia, public health and the sex industry to improve sexual health outcomes. Health Research Policy and Systems, 9, S13. doi: 10.1186/1478-4505-9-S1-S13

Krige, E.J., \& Krige, J.D. (1980). The realm of a rain-queen. Johannesburg, 
South Africa: Juta.

Manabe, N.L. (2010). The silenced voice of initiated Venda women. Unpublished thesis, Faculty of Arts, University of Zululand, South Africa.

Martin Hilber, A., Kenter, E., Redmond, S., Merten, S., Bagnol, B., Low, N., \& Garside, R. (2012). Vaginal practices as women's agency in SubSaharan Africa: a synthesis of meaning and motivation through meta-ethnography. Social Science \& Medicine, 74, 1311-1323. doi: 10.1016/j.socscimed.2011.11.032

Martínez Pérez G., Bagnol B., \& Tomás Aznar C. (2014). Autoerotism, homoerotism, and foreplay in African women who practice labia minora elongation: a review. International Journal of Sexual Health, 26, 314-328. doi: 10.1080/19317611.2014.910585

Martínez Pérez G., Mubanga M., Tomás Aznar C., \& Bagnol B. (2015).

Zambian women in South Africa: Insights into health experiences of labia elongation. The Journal of Sex Research, 52, 857-867. doi: 10.1080/00224499.2014.1003027

Martínez Pérez G., Tomás Aznar C., \& Bagnol B. (2014). Labia Minora Elongation and its implications on the health of women: A Systematic Review. International Journal of Sexual Health, 26, 155171. doi: 10.1080/19317611.2013.851139

Milubi, N.A. (2000). Sexual images: Essence of presence. South African Journal for Folklore Studies, 20, 56-61.

Mwenda, K. (2006). Labia Elongation under African Customary Law. The International Journal of Human Rights, 10, 341-357. doi: $10.1080 / 13642980600976369$

Pétursdóttir, I.D. (2010). "If I had a spear, I would kill the HIV beast": Views of a Malawi village on the HIV epidemics. Master Dissertation. Reykjavik, Iceland: Háskóli Íslands.

Plummer, M., \& Young, L.E. (2010). Grounded theory and feminist inquiry: revitalizing links to the past. West J Nurs Res, 32, 305-321. doi: $10.1177 / 0193945909351298$

Pool, R., Hart, G., Green, G., Harrison, S.,. Nyanzi, S., \& Whitworth, J. (2000). Men's attitudes to condoms and female controlled means of protection against HIV and STDs. Culture, Health \& Sexuality, 2, 197-211. 
1013 Martínez-Pérez, Mubanga, Tomás-Aznar \& Bagnol-Being a Zambian Woman in South Africa

Qureshi, S. (2004). Displaying Sarah Baartman, the 'Hottentot Venus'. Hist Sci, 42, 233-257.

Rasing, T. (2001). The Bush Burnt, the Stones Remain: Female initiation rites in urban Zambia. Hamburg and Leiden: Lit Verlag/ASC.

Sengendo, J., \& Sekatawa, E.K. (1999). A cultural approach to HIV/AIDS prevention and care. Kampala, Uganda: UNESCO.

Shenton, A. (2004). Strategies for ensuring trustworthiness in qualitative research projects. Education for Information, 22, 63-75.

Sikolia, D., Biros, D., Mason, M., \& Weiser, M. (2013). Trustworthiness of grounded theory methodology research in information systems. MWAIS 2013 Proceedings, 16, 6p.

Spring, A. (1973, October). Women's rituals related to fertility among the Luvale of Zambia. Paper presented at the Florida Regional Seminar on sub-Saharan Africa, Tallahassee, Florida.

Tamale, S. (2006). Eroticism, sensuality and 'women's secrets' among the Baganda: A critical analysis. Institute of Development Studies Bulletin, 37, 89-97.

Wuest, J. (1995). Feminist grounded theory: An exploration of the congruency and tensions between two traditions in knowledge discovery source. Qualitative Health Research, 5, 125-137. doi: 10.1177/104973239500500109

Guillermo Martínez Pérez doctorando, Departamento de Enfermería y Fisiatría, Facultad de Ciencias de la Salud, Universidad de Zaragoza, España

E-mail address: gmartinezgabas@gmail.com 